\title{
Chapter 6 \\ The Lion and the Mouse: How and Why \\ Teachers Succeed in Becoming Participants in Children's Ongoing Play
}

This chapter deals with preschool teachers' attempts to participate when children are already engaged in playing, alone or with playmates, and we will focus on when and why teachers seem to succeed (or not) in their attempts to enter ongoing play. In order for a teacher to succeed in becoming a participant in children's ongoing play, the moment of entrance is critical. Communication and play live in the dynamic tension between intersubjectivity and alterity with participants explicitly or implicitly negotiating how to understand what they are doing, or are going to do for example, what and how to play. How teachers do to enter children's play and how they, if becoming a play partner, participate throughout the activity are critical to whether the play will (or will not) continue.

Hence, critical to teachers' participation in play is not only how they attempt to enter but also how they participate once becoming a participant in the activity. Below we will discuss two tensions found regarding why teachers succeed or fail with becoming and maintaining the role of a participant in children's ongoing play. These two are:

- Responding to alterity

- Coordinating as if and as is

\section{Responding to Alterity}

A first matter found regarding why teachers succeed or fail in their attempts to enter and participate in children's ongoing play is how they (and the children) deal with the potential tension between allowing the participants to go on with the negotiated play and the acceptance of expanding the play in a new direction (in theoretical terms, alterity). This tension can regard different parts of the play, for example 
negotiation about possible roles and the direction of the play. This tension is a natural part of expanding and developing ongoing play. However, to expand and maintain play, this tension needs to be managed and below we give examples of such negotiations with different outcomes.

\section{Negotiating Possible Roles}

Below are two examples of the same teacher trying to enter ongoing narrative play at two different times. The focus of these examples is the tension regarding possible roles within play. In the first example, the children have decided to play "The Lion and the Mouse", a for them well-known story. Before the play starts, they negotiate if they are to 'play or talk' (turn 9) and then about the roles of this play (turns 13-22). The teacher takes an active part in these negotiations.

\section{Excerpt 6.1}

\begin{tabular}{l|l|l}
\hline 9 & CIA: & $\begin{array}{l}\text { Mm, but how are we, what shall we do? How will we do it? Shall we see if we can } \\
\text { play or should we talk about it, or should we tell, just tell? }\end{array}$ \\
\hline 10 & Sara & Play, play \\
\hline 11 & CIA: & Shall we just tell the story? \\
\hline 12 & Ted & No, play! \\
\hline 13 & Max & I think they should be hunters \\
\hline 14 & Kalle & No you get to decide by yourself what to be \\
\hline 15 & Max & I wanna be... the mouse \\
\hline 16 & CIA: & Okay \\
\hline 17 & Child & I wanna be the lion \\
\hline 18 & CIA: & Aha \\
\hline 19 & Child & I too wanna be the mouse \\
\hline 20 & CIA: & There can be two mice, right? \\
\hline 21 & Child & I too wanna be the mouse \\
\hline 22 & Max & No, not three \\
\hline
\end{tabular}

Although Max says that there cannot be three mice (turn 22), the teacher decides that it can be so, and the division of roles in the play thus changes on her decision. The teacher is then given the role of the lion. When her role is to enter the narrative, she cannot (as is) enter the house of the mice (she is too big), prompting her to try to change the original storyline by changing the character of her role in the play:

\section{Excerpt 6.2}

80 CIA $\quad$ Aha, so I cannot enter the mouse house, oh no!

81 Kalle It's really small 


\begin{tabular}{l|l|l}
\hline 82 & Max & But we were out... of the nest \\
\hline 83 & CIA: & $\begin{array}{l}\text { But I'm one of those lions who love to write. So maybe I do like this, I write a note } \\
\text { to the mice to COME. Look here, I play that I write COME TO THE PINE A } \\
\text { SURPRISE AWAITS (Kalle several times tries to interrupt her without succeeding) } \\
\text { and I put this note here so perhaps the mice see it (the mice creep away and beep). } \\
\text { Has the mice seen the note? }\end{array}$ \\
\hline 84 & Max & Yes \\
\hline 85 & CIA: & $\begin{array}{l}\text { Look here, here, here, here is the pine (the mice creep to the pine) Raow. I got two } \\
\text { mice at least. Now I'm gonna eat the mice (the mice creep away) }\end{array}$ \\
\hline
\end{tabular}

The actual (as is) obstacle faced by the teacher in the play (turn 80) is first confirmed and explicated by a child (turn 81), before another child, through shifting tempi (turn 82; see Björk-Willén, 2012, for an analysis of temporal shifts when going in and out of play) indicates a recontextualization in terms of as if that in effect solves the problem. In turn 83, the teacher suggests that she is "one of those lions who love to write". She says "Look here, I play that I write" (turn 80), which indicates that she tries to implement this changed role-character into the original storyline within the actions of the play. This is an example of a tension between temporarily sufficient intersubjectivity (mutually playing out a storyline) and dealing with alterity (changing the role character in relation to the storyline). Writing/text is thus introduced into and contextualized in the play in a way that develops the narrative of the play. The children accept the changed role-character and the play continues with this addition to the storyline. Thus, the teacher is free to take the play in an unforeseeable direction. The play develops in a new direction, in what can be understood as a potentially tense 'space' between temporarily sufficient intersubjectivity (i.e., what is temporarily, implicitly or explicitly, sufficiently shared to go on with a joint activity) and alterity (i.e., suggestions on how to reframe the premises of the activity, or expand it in other ways than previously, implicitly or explicitly, agreed upon). The teacher meta-communicates her reframing, including explicating that she plays (turn 83).

Excerpt 6.3 contains another example from when the same teacher tries to introduce a character from another for the children well-known story into the current one.

\section{Excerpt 6.3}

\begin{tabular}{l|l|l}
\hline 107 & CIA: & $\begin{array}{l}\text { But think... do you know the troll Ludenben [Eng., Hairy-Legs]? What if the troll } \\
\text { Ludenben were to jump into the Billy Goats Gruff story. Do you know who } \\
\text { Ludenben is? }\end{array}$ \\
\hline 108 & Lisa & Me! (raises his hand) \\
\hline 109 & CIA: & But do you remember... what story is Lundenben in? \\
\hline 110 & Kalle & Gruff, Gruff [Swedish, Brusarna, brusarna] \\
\hline 111 & CIA: & $\begin{array}{l}\text { Petter and his Four Goats, right? In his hood, no in his stone lived the troll } \\
\text { Ludenben. He was always ANGRY and hungry like a... }\end{array}$ \\
\hline 112 & Child & You can be, you can be Ludenben (to CIA) \\
\hline 113 & Child & Well, we can play that play \\
\hline 114 & Lisa & But then I wanna be the cat \\
\hline
\end{tabular}


The children have been playing Bill Goats Gruff for a while when the teacher suggests that maybe Ludenben could jump into the play (turn 107). After talking about who this troll is (turns 109-111) one child says, "well, we can play that play then" (turn 113). If they are going to do so, another child wants to be the cat (turn 114), which is a role within the story of the troll Ludenben. The emphasis on "that" (turn 113) and the discussion of new roles connected to the narrative of Ludenben indicate that mixing characters from the two stories does not seem to be a possibility, according to the children; rather, you play either Billy Goats Gruff or the troll Ludenben.

Through the processes of dealing with alterity, there is the possibility that also an original storyline 'within' which the play is played will come up for re-negotiation and transformation. How come that the teacher succeeds with adding a changed character into the Lion and the Mouse play but not into the Billy Goats Gruff? It is the same teacher and several of the children are also the same, and both excerpts are examples of a teacher taking a role in the play-acting as if. One explanation could be that the children know the second story better, and for this reason, they are less willing to break the original storyline. Another explanation could be that a previous negotiation in Billy Goats Gruff has made clear that the play is to be played in line with the original storyline. In the negotiation before the Lion and the Mouse play, in contrast, the teacher decides that there can be three mice. Thus, the original storyline was changed (reframed) even before the play started. The teacher deciding about the three mice also showed that she - maybe based on her being the teacher - is free to, without negotiation take the play in a new direction; in her role as teacher, one task she has is to make sure all children who want to are included, and this may necessitate expanding roles that can be played.

The negotiation regards the tension between continuing the joint play project (the Lion and the Mouse) or accepting the suggestion from the teacher on how to somewhat reframe the premises of the play (alterity). That the character of the lion likes to write is perhaps sufficiently harmonious with the original storyline for the children to be able to continue the play with this addition.

\section{Negotiating Possible Directions}

Dealing with alterity is also visible when possible directions are negotiated within ongoing play. Below are two examples of such tensions and how they are dealt with, through further re-negotiation. In the first example, the teacher has been invited by the children to participate in a role-play. The teacher has been assigned the role of the grandmother, and two girls are acting as older sisters. Almost as soon as the play starts, one of the children introduces the activity of reading a book: 


\section{Excerpt 6.4}

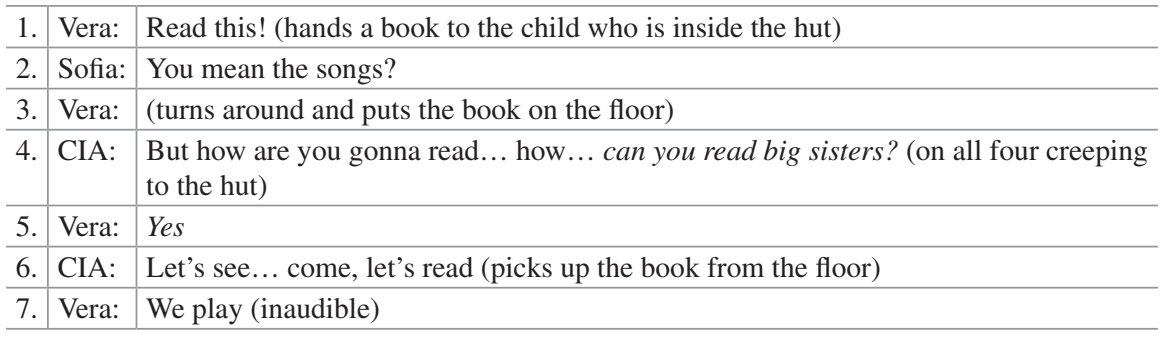

The two children talk about which book to read for the babies (turns 1-2). Then the teacher questions their ability to read the book (turn 4). It is not clear if she initially does this as a teacher (outside the play) or as a grandmother (inside the play); thus, her question can be understood as both as if and as is. However, she quickly adds "older sisters" as in her role as grandmother (making the question one raised within the play form, as if). Then the teacher invites the two girls to read together with her (turn 6). By responding, "we play" (turn 7), the child signals that reading is to be understood as if (pretend-playing to read) and not as is (actually being able to read); alternatively (we do not hear the end of her utterance) suggesting that they play something else (than reading).

\section{Excerpt 6.5}

\begin{tabular}{l|l|l}
\hline 8. & CIA: & Can't you read for me big sisters? (starts browsing the book) \\
\hline 9. & Vera: & Nooo \\
\hline 10. & CIA: & I'm grandma who loves to hear a story (continues browsing the book) \\
\hline 11. & Sofia: & Oh that's right, that's right, we were going to a party today and we're already late \\
\hline 12. & CIA: & Oh... but... \\
\hline 13. & Sofia: & $\begin{array}{l}\text { At school we were going to a party, oh we're late, we have to go! (the girls put } \\
\text { blankets over their shoulders as if they were capes, and exit the room) }\end{array}$ \\
\hline
\end{tabular}

Once again, the teacher tries to invite the "older sisters" to read while she turns the pages of the book (turn 8). She combines as if with as is by calling the girls "older sisters" at the same time as she invites them to read. In responding "No", the child explicitly expresses a different opinion, which can be understood as her having agency and being free to resist taking the play in a particular direction. The teacher continues by saying that she is a grandmother who loves to listen to a story (turn 
10), again implying that she wants the girls to read. The children deal with this suggestion by taking the play into another direction: leaving for a party (turn 11). This turn is made as if imagining going to a party. The teacher is not invited to join the girls to the party; instead, the two girls, in tacit agreement, leave the room (turn 13). Using her play skills, the girl combines experience of going to a party and the importance of being on time, and amends the narrative without losing the thread through employing narrative chains and time markers. The suggestion made by the teacher that the girls read does not manage to expand or maintain the play. Instead, the two children agree to take the play in a new direction, where the teacher is not included. Teacher and children do not at this point establish temporarily sufficient intersubjectivity to go on with a joint play. Instead, the children take the play in a direction that excludes the teacher.

A second example of dealing with alterity in ongoing play is a continuation of the hairdresser's play, previous presented as an example of a teacher entering children's ongoing play by taking a role in the play (see Excerpt 5.6). When this episode continues, as seen in Excerpt 6.6, the teacher is still acting as the customer and the children (Ruth and Klara) are acting as the hairdressers.

\section{Excerpt 6.6}

\begin{tabular}{l|l|l}
\hline 12. & ANNA: & $\begin{array}{l}\text { And then I think I wanna cut my hair a bit (Klara silently combs ANNA's hair) } \\
\text { Have you had many costumers today, Klara? }\end{array}$ \\
\hline 13. & Klara: & Aaaa (continues silently combing ANNA's hair) \\
\hline 14. & ANNA: & So what do you do now? (Klara takes a book and puts it under ANNA's long hair) \\
\hline 15. & Klara: & I take, I take up the hair and then I take it down \\
\hline 16. & ANNA: & Ahaa \\
\hline 17. & Klara: & $\begin{array}{l}\text { Oh, that's right! (stops combing, gets up from the couch, puts the book and comb } \\
\text { away and goes to get a yellow blanket) }\end{array}$ \\
\hline 18. & ANNA: & Do you get a hair wash and so here also before? \\
\hline 19. & Klara: & Mmm \\
\hline 20. & ANNA: & Aaaa perfect (Klara puts the yellow blanket around ANNA's shoulders, it falls off) \\
\hline 21. & Klara: & Shucks! (tries again, ANNA helps her) \\
\hline 22. & ANNA: & $\begin{array}{l}\text { Ah, I'm gonna be so nice in my hair now (Klara attaches the blanket, lifts ANNA's } \\
\text { hair and starts combing it again. Stops after a while, gets up, takes a plastic plate } \\
\text { and brush and stands in front of ANNA) }\end{array}$ \\
\hline 23. & Klara: & Do you wanna have a makeup? \\
\hline 24. & ANNA: & Oh, can you have a makeup here too? \\
\hline 25. & Klara: & Yes, you can be a witch and such \\
\hline 26. & ANNA: & Ahhhh \\
\hline 27. & Klara: & Do you want a makeup like a princess or a witch (inaudible) \\
\hline 28. & ANNA: & Eeeh, I wanna be... a witch \\
\hline 29. & Klara: & $\begin{array}{l}\text { Mmm } \text { Klara stirs the brush on the plate as if there was paint, then does something } \\
\text { with some other plates) }\end{array}$ \\
\hline 30. & ANNA: & What a place, you can cut your hair and get a makeup here! \\
\hline 31. & Klara: & $\begin{array}{l}\text { So } \text { (Klara returns to ANNA and starts pretending to put makeup on her face with } \\
\text { the brush) }\end{array}$ \\
\hline & & \\
\hline
\end{tabular}


Both the teacher and the children act as if (see turns 12-13), and, for example, by putting the blanket on the teacher's shoulders (turns 20-21) the girls show that they have experience of being at the hairdresser's. The teacher acts as if by asking questions about possible treatments (turn 18). Thus, within the frame of the play, as is (what actually happens to a costumer at the hairdresser's) is interweaved with as if. There is no obvious goal or narrative in the play. Rather, it is open ended and continuously negotiated through the actions of the teacher and the children; actions that are in line with being hairdresser and customer. However, in turn 23, one of the girls introduces a different perspective (alterity) into the play by asking if the customer wants some make up. The teacher answers with some surprise in her voice, but still in her role as customer (turn 24). Her answer shows that it is not obvious that you can get a make-up at the hairdresser's, but she aligns and hands over to the girl to decide if this can be incorporated and, thus, the direction of the play. Through this response, the child is free to take the play in new directions and she continues the extension by introducing the opportunity to get a make-up as a princess or a witch (turns 25 and 27). The teacher confirms the new direction, partly by saying that she wants to be a witch and partly by emphasising the quality of the place where you can get both a haircut and a make-up (turns 28 and 30). Thus, negotiating the new frame of the play is made within the frame of the play as if, rather than through stepping outside it. By dealing with alterity in this way, the teacher helps the children to combine two different previous experience (being at the hairdresser's and getting a make-up as a witch or princess) into something new within the frame of the play. Combining previous experience into a new form is an important feature of creativity, as conceptualised from a Vygotskian point of view (Vygotsky, 1930/2004). In response to this expansion of the play, the teacher a little while later leaves the hairdresser's as a flying witch.

\section{Coordinating as If and as Is}

A second reason why teachers seem to succeed or fail in their attempts to enter and participate in children's ongoing play is how they and the children coordinate as if and $a s$ is. As seen in previous excerpts in this chapter, the participants consistently shift between these modes of talking; the line between these being highly permeable. However, this permeability sometimes makes it unclear for the participants if an utterance is to be understood as if or as is, that is whether or not it is to be taken as an action in the play. Uncertainty regarding as is and as if becomes particularly visible in narrative play. Playing as such implies as if, but when playing a canonical story in line with the original storyline, the storyline gains standing as is. The previously presented example of Billy Goats Gruff (Excerpt 6.3) is an example of how adhering to a well-known narrative frame hinders the children from being free to take the play in unforeseeable directions. 
In the following, the delicate issue of coordinating as if and as is is illustrated with excerpts from two other play activities. In the first example, a teacher is trying to initiate a play with trains with a boy (approximately 2 years old). She does this by asking meta-questions to the child:

\section{Excerpt 6.7}

\begin{tabular}{l|l|l}
\hline 1. & KAREN: & Then who wants to drive that ambulance? \\
\hline 2. & Martin: & My dad/my dad \\
\hline 3. & KAREN: & Who's driving grandma and grandpa's car? Shall I drive it? \\
\hline 4. & Martin: & Grandma and grandpa are gonna drive it \\
\hline
\end{tabular}

When the teacher asks, "then who wants to drive that ambulance" (turn 1), the child answers "my dad" (turn 2). In real life, the father of this child is an ambulance driver, why both the question from the teacher and the answer from the child can be understood as is. Then the teacher asks who is driving the grandparents' car (turn 3). Again, this question is about who of them that should move the car physically in the play. The teacher offers to do this (she has no role in the play, thus the "I" [turn $3]$ in the utterance refers to her as teacher, as is). However, the child's answer indicates that he is talking as if. If connecting this second answer to the answer to the first question, both answers could be as if within the play (hence, the two different writings in the excerpt, one in plain writing and one in italics). Thus, it is possible that the teacher talks as is while the child answers as if. At this point, there is no indicator that the two participants have established some intersubjectivity, allowing them to go on with a shared activity; they may, in effect, be engaged in parallel ones, talking past each other.

Sometimes this doubtfulness regarding whether actions are to be taken as as if or as is becomes a matter for meta-communication. In Excerpt 6.8, three children (Linn, My and Sam) sit under a table. There is a blanket over the table giving the impression of a hut.

\section{Excerpt 6.8}

\begin{tabular}{l|l|l}
\hline 1 & Linn & $\begin{array}{l}\text { I found that one before (looks at CIA and points at the imaginary phone My holds to } \\
\text { her ear), the one that My has }\end{array}$ \\
\hline 2 & CIA: & $\begin{array}{l}\text { What are they saying, what are they saying, My? (looking at My who is } \\
\text { "on the phone") }\end{array}$ \\
\hline 3 & My & $\begin{array}{l}\text { The thieves are gone but they cannot lock. So they have to come here while the } \\
\text { builders rebuild it. It takes thirty-seven months }\end{array}$ \\
\hline 4 & CIA: & Oh, so the neighbors say that in thirty-seven months they cannot live in their house? \\
\hline 5 & My & Yes, as they must, so we need to share our house \\
\hline 6 & CIA: & Aha \\
\hline 7 & My & We have to be nice \\
\hline 8 & CIA: & Shall I sit here? Can I do that? (creeps in under the table) \\
\hline
\end{tabular}




\begin{tabular}{l|l|l}
\hline 9 & My & $\begin{array}{l}\text { We have to be nice to the neighbours so they... we need to be nice to the neighbours } \\
\text { so they, so they can be, be in our house. }\end{array}$ \\
\hline 10 & Sam & Even the castle fell on their house \\
\hline 11 & CIA: & Aha, noo \\
\hline 12 & My & Yes, like this pfff (shows with her hands how the castle fell) \\
\hline 13 & Linn & But... \\
\hline 14 & My & And it was on their cabin. Not good, right? \\
\hline 15 & Linn & Wait... it came on our house but it, it's extra stone \\
\hline 16 & CIA: & In the play or for real? \\
\hline 17 & Linn & In the play \\
\hline 18 & CIA: & Okay \\
\hline
\end{tabular}

When the recording starts, one child is trying to get the teacher's attention by saying that she had it first, referring to a pretend telephone (turn 1). However, the teacher neglects this as is talk and instead starts to communicate $a$ s if with another child (turn 2). Thus, she clearly shows that she is now taking part in the children's play, as if. However, later, in turn 16, the teacher is no longer sure if one of the children is talking within the play or not. Something in what the child says makes the teacher unsure about whether the child is talking as if or as is. To re-establish mutual ground (temporarily sufficient intersubjectivity), the teacher asks, "In the play or for real" (turn 16), which the child answers, "in the play". Through this meta-communication, mutual ground is re-established.

\section{Discussion}

In this chapter we have focused on when and why teachers seem to succeed (or not) in their attempts to enter ongoing play. In this analysis, the theoretical notions of intersubjectivity and alterity have been important. To become a participant in children's ongoing play means to balance the tension between intersubjectivity and alterity, that is, sufficient mutual ground for engaging in a shared activity and being open to unforeseeable development, respectively, as well as coordinating as if and as is. This is of substantial importance in the moment of entering in order for the teacher to get access to a play, but as mentioned, our analysis shows that it is not only the teacher's first attempt to enter ongoing play that is critical. When the teacher has become a participant in ongoing play, the balancing and coordinating continues and then the ability to latch on to what the children enact and say becomes critical to the development of the play. To become and remain a participant in children's ongoing play the teacher needs to be sensitive to children's initiatives and be able to balance between these and their own contributions within the activity. This is a matter of contributing to and maintaining play, and thus an important play skill required by teachers. 


\section{References}

Björk-Willén, P. (2012). "Being doggy": Disputes embedded in preschooler's family role-play. In S. Danby \& M. Theobald (Eds.), Disputes in everyday life: Social and moral orders of children and young people (pp. 119-140). Bingley, UK: Emerald.

Vygotsky, L. S. (2004). Imagination and creativity in childhood. Journal of Russian and East European Psychology, 42(1), 7-97. (Original work published 1930).

Open Access This chapter is licensed under the terms of the Creative Commons Attribution 4.0 International License (http://creativecommons.org/licenses/by/4.0/), which permits use, sharing, adaptation, distribution and reproduction in any medium or format, as long as you give appropriate credit to the original author(s) and the source, provide a link to the Creative Commons licence and indicate if changes were made.

The images or other third party material in this chapter are included in the chapter's Creative Commons licence, unless indicated otherwise in a credit line to the material. If material is not included in the chapter's Creative Commons licence and your intended use is not permitted by statutory regulation or exceeds the permitted use, you will need to obtain permission directly from the copyright holder. 